\title{
Molecular genetic diversity and origin of Chinese domestic duck breeds
}

\author{
HUI-FANG LI', WEN-QI ZHU, WEI-TAO SONG, JING-TING SHU, WEI HAN and KUAN-WEI CHEN \\ Institute of Poultry Science, Chinese Academy of Agriculture Science, Yangzhou, People's Republic of China
}

\begin{abstract}
The 667 bp control region of mitochondrial DNA from 8 representative domestic duck breeds in China, which were all native preserved duck breeds, and a mallard (6 Anas zonorhyncha individuals) were sequenced. The genetic polymorphism and the origin of the 8 domestic ducks were analysed. The result showed that the haplotype diversity $(\mathrm{Hd})$ and average nucleotide diversity $(\mathrm{Pi})$ were 0.67136 and $0.19 \%$, respectively. $\mathrm{Hd}$ and $\mathrm{Pi}$ of Youxian Sheldrake were the highest in the 8 domestic duck breeds. Kimura-2 parameter genetic distance between the breeds ranged from 0.00056 to 0.00414 . The NJ phylogenetic tree and reduced median-joining network chart were constructed by the total 38 haplotypes and 96 sequences, which included 12 sequences of Anas platyrhynchos from GenBank, 6 sequences of Anas zonorhyncha from GenBank and 78 sequences of this study (72 domestic ducks and 6 Anas zonorhyncha). The maternal origin of the 8 domestic ducks all originated from Anas platyrhynchos.
\end{abstract}

Keywords: domestic duck, D-loop region, genetic diversity, origin

\section{Zusammenfassung}

\section{Molekulargenetische Vielfalt und die Herkunft der chinesischen Hausentenrassen}

Die 667 bp-Kontrollregion der mitochondrialen DNS von 8 Hausentenrassen aus China, die Maßnahmen zur Lebenderhaltung erfahren, und einer Stockente (6 Anas zonorhyncha Individuen) wurde sequenziert. Der genetische Polymorphismus und die Herkunft der 8 Hausentenrassen wurden analysiert. Die Haplotyp-(Hd) und die Nukleotid-Diversität (Pi) betrugen 0.67136 und $0.19 \%$. Der höchste $\mathrm{Hd}$ - und Pi-Wert der 8 Hausentenrassen fand sich bei der Youxian-Sheldrake-Ente. Die genetische Distanz (Kimura-2-Parameter) zwischen den Rassen reichte von 0.00056 bis 0.00414 . Der »Neighborhood joining« (NJ) phylogenetische Baum und das reduzierte »Median-Joining«-Netzwerkdiagramm wurde aus 38 Haplotypen und 96 Sequenzen erstellt, einschließlich 12 Sequenzen von Anas platyrhynchos und 6 Sequenzen von Anas zonorhyncha aus GenBank sowie 78 Sequenzen dieser Untersuchung (72 Hausenten und 6 Anas zonorhyncha). Alle 8 Hausentenrassen stammen mütterlichseits von Anas platyrhynchos ab.

Schlüsselwörter: Hausente, D-loop-Region, genetische Vielfalt, Herkunft 


\section{Introduction}

Taxonomically, the duck species (domestic duck) belongs to the Anseriformes, Anatidae, Anas platyrhynchos domestic. There were two views about the origin and evolution of Chinese domestic ducks in academia. The monadism view affirmed by overseas scholars was that Chinese domestic ducks were originated from wide Anas platyrhynchos. The dualism view was that Chinese domestic ducks were originated from archaic Anas platyrhynchos and Anas zonorhyncha, domesticated in different areas respectively, or from the generations crossed by Anas platyrhynchos and Anas zonorhyncha (QIU 1998, CHANG 1995).

The mitochondrial DNA ( $m t D N A$ ) was considered to be the effect genetic marker for the genetic structure among populations and species and the phylogenetic evolution, because of the characters of classical maternal inheritance, less recombinant, rapid evolution, less selection pressure, great genetic variance and so on, and the displacement region (D-loop) especially. Recently, this molecule marker was extensively used on the animal phylogenetic evolution and genetic diversity (RANDI et al. 1998, SACCONE et al. 2000, NIU et al. 2002, Ll et al. 2008).

The Chinese domestic duck in particular is one of the earliest domesticated fowls in the world (CASS 1979). China is particularly rich in Waterfowl genetic resources; in 2002, the state identified 27 domestic duck breeds. But, there were only a few studies on the origin of these domestic ducks. The 8 representative breeds including various breed types in China were selected in our study. In this survey, combined with the sequences of Anas platyrhynchos and Anas zonorhyncha, the mtDNA D-loop sequences from 8 representative domestic duck breeds were amplified, sequenced, and analysed to reveal the diversity, origin and evolution of these breeds. The conclusion could provide theoretic basis for the reasonable taxon, protection, development and utilization of the local ducks and offered basic material for the origin and genetic differentiations of the domestic ducks.

\section{Material and methods}

\section{Specimen collection and DNA extraction}

The blood samples of the 8 representative duck breeds were collected from the preservation farms respectively, as follows (Table 1): Beijing (BJ, $n=8)$, Jianchang (JC, $n=8)$, Youxian Sheldrake ( $Y X, n=12)$, Shaoxing ( $S X, n=8)$, Putian Black (PT, $n=8)$, Jinding (JD, $n=8)$, Liancheng White ( $(\mathrm{C}, \mathrm{n}=8)$, Gaoyou ( $\mathrm{GY}, \mathrm{n}=12)$. The sample of Anas zonorhyncha $(\mathrm{BZ}, \mathrm{n}=6)$ was collected from the Qianjiang fowl breeding farm in Hangzhou City, Zhejiang Province, P.R. China. All the sample individuals represented their own breed respectively. The sex ratio of each breed was 1 male to 1 female. The genetic relationship between ducks should be avoided as much as possible.

\section{PCR amplification and DNA sequencing}

Polymerase chain reaction (PCR) was performed to amplify part of the mtDNA control region. The primers reported by SORENSON et al. (1999) were used to amplify the target region. The corresponding sequences were L78 5'-GTT ATT TGG TTA TG CAT ATC GTG-3', and H774 5'-CCA TAT ACG CCA ACC GTC TC-3'. 
The PCR reaction was carried out on an Eppendorf Mastercycle. The reaction recipe contained $2.5 \mu \mathrm{l}$ 10×Buffer, $2.5 \mu \mathrm{ldNTPs}(2.5 \mathrm{mM}), 2.5 \mu \mathrm{Mg} \mathrm{Mg}^{2+}(25 \mathrm{mM}), 1 \mu \mathrm{l}$ each primer $(25 \mathrm{pmol} / \mu \mathrm{l}), 3.0$ $\mu \mathrm{l}$ genomic DNA $(50 \mathrm{ng} / \mu \mathrm{l}), 0.2 \mathrm{Taq}$ polymerase $(5 \mathrm{U} / \mu \mathrm{l})$. The thermal cycling profile for $\mathrm{mtDNA}$ was $5 \mathrm{~min}$ preheat at $95^{\circ} \mathrm{C}$, followed by 35 cycles of $45 \mathrm{~s}$ at $94^{\circ} \mathrm{C}, 45 \mathrm{~s}$ at $58^{\circ} \mathrm{C}, 1 \mathrm{~min}$ at $72^{\circ} \mathrm{C}$, a final extension of $10 \mathrm{~min}$ at $72^{\circ} \mathrm{C}$, and conservation at $4^{\circ} \mathrm{C}$. PCR products were agarose gel-purified and sequenced on an $\mathrm{ABI}$ Prism 3730 DNA Analyzer in both directions by primer walking using a BigDye Terminator V. 3.1 Cycle Sequencing Kit (ABI, Foster City, CA).

Table 1

Conservation status and characteristics of the 8 domestic duck breeds

Erhaltung und Eigenschaften der 8 Hausentenrassen

\begin{tabular}{lrcrcc}
\hline Breed & Amount & Conservation type & Longitude and latitude & Type & Feather color \\
\hline BJ & 200000 & Conservation farm & $39^{\circ} 15^{\prime} \mathrm{N}, 116^{\circ} 10^{\prime} \mathrm{E}$ & Meat & White \\
JC & 2000 & Conservation farm & $26^{\circ} 54^{\prime} \mathrm{N}, 102^{\circ} 12^{\prime} \mathrm{E}$ & Meat and Egg & Spotty \\
YX & 500000 & Conservation farm/zone & $26^{\circ} 72^{\prime} \mathrm{N}, 113^{\circ} 27^{\prime} \mathrm{E}$ & $\mathrm{Egg}$ & Spotty \\
SX & 20000000 & Conservation farm/zone & $30^{\circ} 12^{\prime} \mathrm{N}, 120^{\circ} 12^{\prime} \mathrm{E}$ & $\mathrm{Egg}$ & Spotty \\
PT & 1000000 & Conservation farm/zone & $25^{\circ} 24^{\prime} \mathrm{N}, 119^{\circ} 08^{\prime} \mathrm{E}$ & $\mathrm{Egg}$ & Spotty \\
JD & 3500000 & Conservation farm/zone & $24^{\circ} 18^{\prime} \mathrm{N}, 117^{\circ} 48^{\prime} \mathrm{E}$ & Egg & Spotty \\
LC & 2000000 & Conservation farm/zone & $25^{\circ} 42^{\prime} \mathrm{N}, 116^{\circ} 42^{\prime} \mathrm{E}$ & Egg and medicine & Spotty \\
GY & 100000 & Conservation farm/zone & $32^{\circ} 47^{\prime} \mathrm{N}, 119^{\circ} 25^{\prime} \mathrm{E}$ & Egg and meat & Spotty \\
\hline
\end{tabular}

\section{Data analysis}

Electropherograms were obtained using the program Chromas and manually checked insuring the veracity of the DNA sequences. Sequence alignments were performed using DNAman (6.0.40). Haplotype numbers, nucleotide variable sites, haplotype diversity, nucleotide diversity (NEI 1982) were calculated using DnaSP V.4.10.7 (ROZAS 2003). Ignoring the insertion/deletion mutations, the same sequences were considered to be one haplotype. The same mtDNA D-loop control region sequences of Anas platyrhynchos and Anas zonorhyncha were acquired from GenBank. Kimura 2-parameter distances between breeds were estimated in Mega v. 3.1 (KUMAR et al. 2004) and a neighbour-joining tree was then constructed. The haplotype network was constructed using the software NETWORK 4.5.0.1.

Table 2

Haplotype diversity $(\mathrm{Hd})$, average number of differences $(\mathrm{K})$ and nucleotide diversity (Pi) of D-loop in 8 domestic duck breeds

Haplotypdiversität (Hd), durchschnittliche Anzahl der Unterschiede und Nukleotiddiversität (Pi) der D-loop bei 8 Hausentenrassen

\begin{tabular}{lccclll}
\hline Breeds & Size & $\begin{array}{c}\text { No. of } \\
\text { haplotypes }\end{array}$ & Haplotypes, \% & $\mathrm{Hd}$ & $\mathrm{K}$ & $\mathrm{Pi}$ \\
\hline BJ & 8 & 2 & $25.0 \%$ & 0.42857 & 0.42857 & 0.00064 \\
JC & 8 & 3 & $37.5 \%$ & 0.46429 & 0.50000 & 0.00075 \\
YX & 12 & 7 & $58.3 \%$ & 0.83333 & 2.13636 & 0.00320 \\
SX & 8 & 2 & $25.0 \%$ & 0.25000 & 0.25000 & 0.00037 \\
PT & 8 & 3 & $37.5 \%$ & 0.46429 & 0.75000 & 0.00112 \\
JD & 8 & 3 & $37.5 \%$ & 0.7500 & 0.96429 & 0.00145 \\
LC & 8 & 3 & $37.5 \%$ & 0.60714 & 0.78571 & 0.00118 \\
GY & 12 & 4 & $33.3 \%$ & 0.56061 & 0.63636 & 0.00095 \\
\hline
\end{tabular}




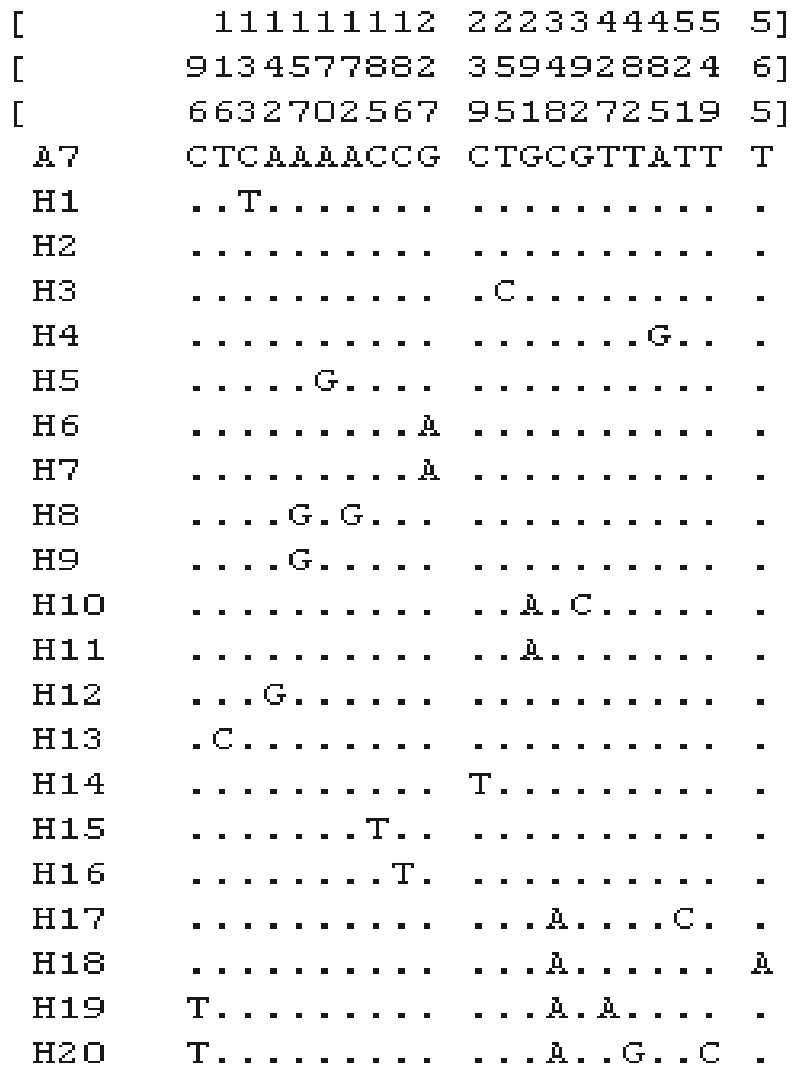

Figure 1

$\mathrm{H} 1-\mathrm{H} 20$ indicates the haplotypes of 72 domestic ducks

Variable sites in mtDNA D-loop of haplotpyes of domestic ducks

H1 - H2O zeigt die Haplotypen von 72 Hausenten an

Unterschiedliche Standorte in der mtDNA D-loop der Haplotypen von Hausenten

Table 3

Kimura 2-parameter distances (above diagonal) and standard error (below diagonal) of D-loop in 8 domestic duck breeds

Kimura 2-Parameter-Distanzen (über der Diagonalen) und Standardfehler (unter der Diagonalen) in der D-loop von 8 Hausentenrassen

\begin{tabular}{lcccccccc}
\hline Breed & BJ & JC & YX & SX & PT & JD & LC & GY \\
\hline BJ & & 0.00044 & 0.00088 & 0.00039 & 0.00046 & 0.00120 & 0.00149 & 0.00047 \\
JC & 0.00075 & & 0.00080 & 0.00031 & 0.00040 & 0.00119 & 0.00149 & 0.00040 \\
YX & 0.00226 & 0.00226 & & 0.00076 & 0.00082 & 0.00143 & 0.00163 & 0.00079 \\
SX & 0.00056 & 0.00056 & 0.00207 & & 0.00036 & 0.00119 & 0.00149 & 0.00036 \\
PT & 0.00094 & 0.00094 & 0.00241 & 0.00075 & & 0.00123 & 0.00148 & 0.00043 \\
JD & 0.00207 & 0.00207 & 0.00348 & 0.00188 & 0.00211 & & 0.00191 & 0.00121 \\
LC & 0.00263 & 0.00263 & 0.00414 & 0.00244 & 0.00282 & 0.00395 & & 0.00151 \\
GY & 0.00088 & 0.00088 & 0.00238 & 0.00069 & 0.00106 & 0.00219 & 0.00276 & \\
\hline
\end{tabular}




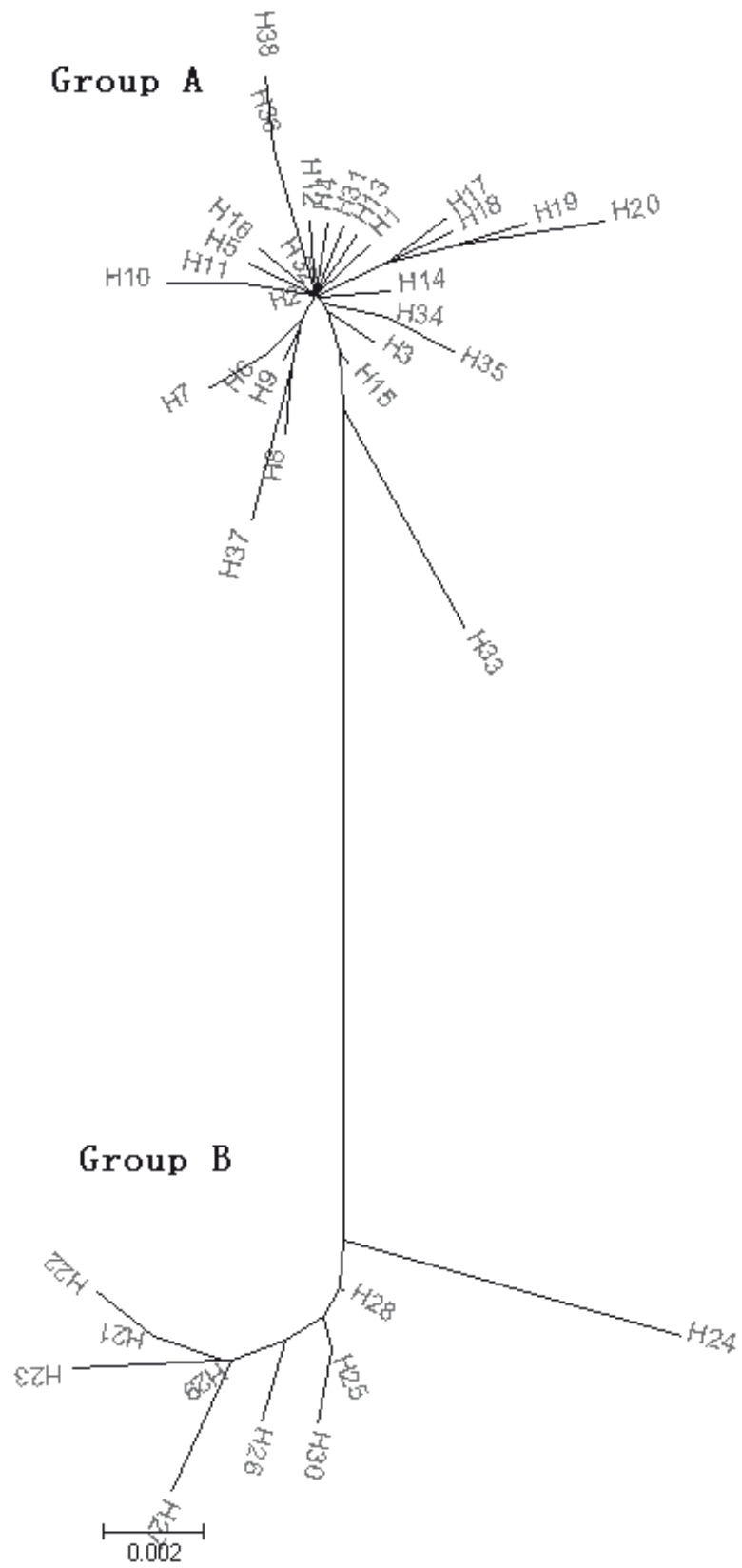

Figure 2

$\mathrm{H} 1-\mathrm{H} 20$ represented the haplotypes in the 8 domestic duck breeds

H21 H30 represented haplotypes of Anas zonorhyncha

$\mathrm{H} 31 \sim \mathrm{H} 38$ represented haplotypes of Anas platyrhynchos

H1-H20 stellt die Haplotypen bei 8 Hausentenrassen dar

H21 H30 stellt die Haplotypen bei Anas zonorhyncha dar

H31 H3 stellt die Haplotypen bei Anas platyrhynchos dar 


\section{Group A}

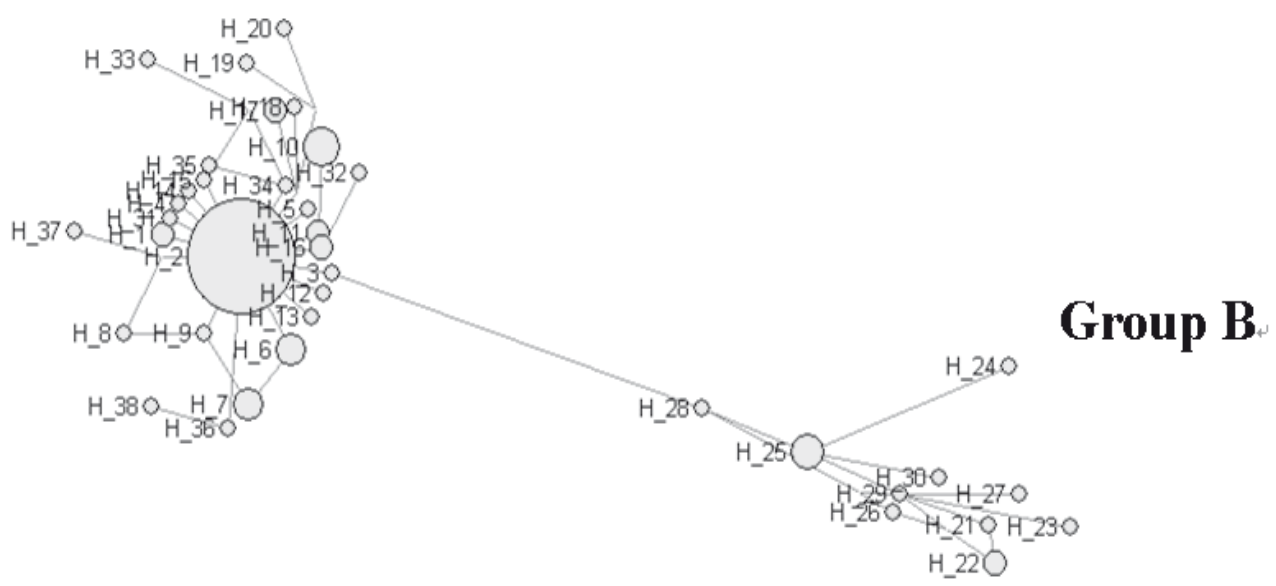

Figure 3

$\mathrm{H} 1-\mathrm{H} 20$ represented the haplotypes in the 8 domestic duck breeds

$\mathrm{H} 21 \sim \mathrm{H} 30$ represented haplotypes of Anas zonorhyncha

$\mathrm{H} 31 \sim \mathrm{H} 38$ represented haplotypes of Anas platyrhynchos

H1-H2O stellt die Haplotypen bei 8 Hausentenrassen dar

H21 H30 stellt die Haplotypen bei Anas zonorhyncha dar

H31 H3 stellt die Haplotypen bei Anas platyrhynchos dar

\section{Results and discussion}

Genetic diversity and distance among 8 domestic duck breeds

Table 2 showed that the largest number of haplotype was found in YX (7) with the haplotype proportion of $58.3 \%$, the second in GY (4), 33.3\%, and then in the JC, PT, JD and LC (3), $37.5 \%$, respectively, the lowest in BJ and SX (2), $25.0 \%$, respectively. The average haplotype diversity $(\mathrm{Hd})$, nucleotide diversity $(\mathrm{Pi})$ and nucleotide difference $(\mathrm{K})$ of the 8 domestic duck populations was $0.67136,0.00192$ and 1.27856 , respectively, of which $\mathrm{YX}$ was the highest $(\mathrm{Hd}=0.83333, \mathrm{Pi}=0.00322, \mathrm{~K}=13636)$.

Kimura 2-parameter distances of mtDNA D-loop in 8 duck breeds were showed as table 3. The genetic distances between the 8 duck breeds were ranged from 0.00056 to 0.00414 , the largest was between LC and YX, followed by LC and JD, and the lowest was between SX and JC.

$\mathrm{Hd}$ and $\mathrm{Pi}$ of 8 domestic duck breeds $(0.67136,0.19 \%)$ were lower than Anas platyrhynchos of that region (0.987, $0.83 \%$ ) (KULIKOVA et al. 2005). Compared to other animals, this result was similar to swine (0.122\%) (LAN et al. 1995), significantly less than yak (1.231\%) (LAl et al. 2005) and scalper (2.16\%) (LIU et al. 2006) and significantly higher than chicken $(<0.001 \%)$ (WAKANA et al. 1986). Haplotype diversity (Hd) and nucleotide diversity (Pi) of populations were main indexes for evaluating the mtDNA variation and genetic diversity of breed or population. The greater $\mathrm{Hd}$ and $\mathrm{Pi}$, the more rich the genetic diversity. $\mathrm{Hd}$ and $\mathrm{Pi}$ were lower in $B J$ and SX, and highest in YX. The genetic diversity was mainly affected by the selection period and pressure. The selection period and pressure of BJ and SX were earlier and bigger 
than YX's. In general, we considered that the nucleotide diversity of Chinese domestic ducks was low, and average nucleotide difference $(K)$ was greater compared to nucleotide diversity. It indicated that the genetic diversity of Chinese domestic ducks was low, the interspecies of which was less than within-species.

In recent years, genetic distance and genetic differentiation of Chinese domestic ducks were analysed by SSR marker (LI et al. 2006 a,b and 2007), and some valuable conclusions were obtained. In our investigation, the genetic distances were $0.00056-0.00414$. The greatest genetic distance in our test was between LC and other breeds, which was consistent with the report of YAN et al. (2005). LC with a dual purpose for medicine and egg, which was bred for the medicinal trait and laying performance for a long time, differed from other domestic ducks in phenotype and genome.

\section{Origin and evolution of 8 domestic duck breeds}

The mtDNA phylogeny of the ducks comprises two divergent haplotype groups, group A and group B (AVISE et al. 1990, JOHNSON et al. 1999, KULIKOVA et al. 2004 \& 2005). The NJ phylogenetic tree (Figure 2) and reduced median-joining network chart (Figure 3) were constructed by the total 38 haplotypes and 96 sequences which included 12 Anas platyrhynchos (AY506877, AY506906, AY506925, AY506930, AY506941, AY506974, AY506977, AY506982, AY506883, AY506873, AY506874, AY506904), 6 Anas zonorhyncha (AY506946, AY506958, AY506960, AY506964, AY506949, AY506945) and 78 sequences of this study (72 domestic ducks and 6 Anas zonorhyncha). As the figure 2 and figure 3 showed, Chinese domestic ducks were clustered into the haplotype cluster $A$, and the maternal origin of the 8 domestic ducks was Anas platyrhynchos.

Most of Chinese duck breeds were formed in Ming and Qing dynasty, such as Pekin duck, Shaoxing duck, Gaoyou duck, the domesticated history was less than one thousand years. At present, there are lots of reports about the origin of Chinese domestic duck, but the origin dispute still existed. Based on mtDNA molecular marker, 8 representative domestic duck breeds were analysed to reveal the diversity, origin and evolution of Chinese domestic duck breeds.

Parts of domestic ducks genetic diversity and the genetic relationship among domestic ducks, Anas platyrhynchos and Anas zonorhyncha were analysed by CHEN et al. (2001) and the results showed that both of Anas platyrhynchos and Anas zonorhyncha contributed to domestic duck evolution. Genomic DNA polymorphism among eight domestic ducks and two wild ducks by using AFLP technique was estimated. The eight domestic duck breeds were originated from both Anas platyrhynchos and Anas zonorhyncha by genetic distance and variance analysis (YAN et al. 2005). The analysis of Genomic DNA polymorphism among three famous duck breeds of domestic ducks (Jinding duck, Liancheng white duck, Shanma duck) and two wild ducks (Anas platyrhynchos and Anas zonorhyncha) in Fujian province by SSR indicated that Anas platyrhynchos contributed more to domestic duck evolution than Anas zonorhyncha (CHEN et al. 2006). In general, the three reports showed that the Chinese domestic ducks were originated from Anas platyrhynchos and Anas zonorhyncha which supported the dualism of duck origin.

The mtDNA phylogeny of the duck comprises two divergent haplotype groups, group A and group B (AVISE et al. 1990). Group A haplotypes are most common and are found worldwide. 
$B$ haplotypes occur at high frequencies throughout North America and in frequently in North Asia. Mallards from Asia are attributed to the Group A haplotype clade; spot-billed ducks are attributed to group A or B haplotype clades. The B haplotype from North Asia, however, differs from all other group $B$ haplotypes, forming a separate subclade (SB) nested within the group B clade (accession nos. AY506873, AY506874, and AY506904). Actually, the spotbilled duck was not closely related to Asian Mallards but instead is more closely related to the Mottled Duck (JOHNSON and SORENSON 1999). DNA sequencing revealed clades that correspond to AVISE et al. (1990) group A and group B mtDNA. In this study, 20 haplotypes of domestic ducks were only clustered to group $A$ and also no evidence of contribution of Anas zonorhyncha to the maternal origin of domestic duck breeds. The study conclusion is that Chinese domestic ducks were only originated from Anas platyrhynchos based on mitochondrial DNA analysis.

\section{Acknowledgements}

This work was supported by the Jiangsu Technological Service Platform (No. BM2008170) and the National Technological supporting project of P.R. China (No. 2008BDAB2B08).

\section{References}

CASS (Chinese Academy of Social Sciences) (1979) Archaeological perspectives on Yin ruins, Anyang excavations in 1969-1977, China. Acta Archaeological Sinica, Institute of Archaeology 1

Chang H (1995) Conspectus of genetic resources of livestock. Chinese Agriculture Press, Beijing, China

Chen Q, Huang ZY, Yan FH, Lu LJ (2006) Analysis of Genetic Relationship among Some Local Domestic Ducks in Fujian Province. Journal of Quanzhou Normal University (Natural Science Edition) 6, 90-4

Chen YX, Chen, XL, Lv LJ, Zhao ZH, Lai YZ (2001) Research for Domestic Duck Resources and the Strain Breeding. Journal of Xiamen University (Natural Science Edition) 2, 642-6

John C, Avise C, Davison A, William S, Nelson (1990) Mitochondrial gene trees and the evolutionary relationship of Mallard and Black Ducks Evolution 44, 1109-19

Johnson KP and Sorenson MD (1999) Phylogeny and biogeography of dabbling ducks (Genus: Anas): A comparison of molecular and morphological evidence. Auk 116, 792-805

Kulikova IV, Zhuravlev YN, McCracken KG (2004) Asymmetric hybridization and sex-biased gene flow between eastern spot-billed ducks (Anas zonorhyncha) and mallards (Anas platyrhynchos) in the Russian Far East. Auk 121, 930-49

Kulikova IV, Drovetski SV, Gibson DD, Harrigan RJ, Rohwer S, Winker K, Zhuravlev YN, McCracken KG (2005) Phylogeography of the mallard (Anas platyrhynchos): Hybridization, dispersal, and lineage sorting contribute to complex geographic structure. Auk 122, 949-65

Kumar S, Tamura K, Nei M (2004) MEGA3: Integrated software for molecular evolutionary genetics analysis and sequence alignment. Brief Bioinform 5, 150-63

Lan H, Wang W, Shi LM (1995) Genetic Diversity of Mitochondrial DNA Sequences in Swine and Wild Boar in southwest. J Genet Genomics 1, 28-33

Lai JS, Wang L, Liu YP (2005) Study on Mitochondrial DNA Genetic Polymorphism of Some Yak Breeds in China. Acta Genetica Sinica 32, 463-70

Li HF, Li BC, Chen KW, Yang N, Ma YH, Tang QP, Tu YJ (2006a) Study on Molecular Genetic Diversity of Native Duck Breeds in China. acta veterinaria et zootechnica Sinica 11, 1107-13

Li HF, Yang N, Ma YH, Chen GH, Tu YJ, Tang QP, Chen KW (2006b) Study on Molecular Genetic Diversity of Native Egg-laying Duck Breed Population in China. J Shandong Agricul Univ (Natural Science Edition) 4, 536-40 
Li HF, Li BC, Ma YH, Tang QP, Chen KW, Tu YJ (2007) Molecular Genetic Diversity of Fujian Domestic Duck Breeds. Chinese J Appl Ecol 2, 463-6

Li QF, Li Y, Zhao XB, Pan ZX, Liu ZS (2008) Sequencing D-loop region of mitochondrial DNA in yak and study on its taxonomic status in bovines. Acta veterinaria et zootechnica Sinica 1, 1-6

Liu RY, Xia XL, Lei CZ (2006) Genetic Diversity of Mitochondrial DNA D-loop Sequences in Cattle Breeds in Guizhou. Gene 28 (3), 279-84

Nei M (1982) Evolution of human races at the gene level. Prog Clin Biol Res Pt A, 167-181

Niu D, Fu Y, Luo J, Ruan H, Yu XP, Chen G, Zhang YP (2002) The Origin and Genetic Diversity of Chinese Native Chicken Breeds. Biochem Genet 40, 163-74

Qiu XP (1989) China Chicken Breeds Collection. Scientific and Technical Publishers, Shanghai, China

Randi E and Lueehini V (1998) Organization and evolution of the mitochondrial DNA control region in the avian genus Alectoris. J Mol Evol 4, 449-62

Rozas J, Sánchez-DelBarrio JC, Messeguer X (2003) DnaSP, DNA polymorphism analyses by the coalescent and other methods. Bioinformatics 19, 2496-7

Saccone C, Gissi C, Lanave C, Larizza A, Pesole G, Reyes A (2000) Evolution of the mitochondrial genetic system, an overview. Gene 1, 153-9

Sorenson MD, Jennifer C, Ast DE, Yuri D T, and Mindell DP (1999) Primers for a PCR-based approach to mitochondrial genome sequencing in birds and other vertebrates. Mol Phylogenet Evol 12, 105-14

Wakana S, Watanabe T, Hayashi Y, Tomita T (1986) A Variant in the Restriction Endonuclease Cleavage Pattern of Mitochondrial DNA in the Domestic Fowl. Gallus Gallus Domesticus. Anim Genet 2, 159-68

Yan FH, Zuo ZH, Chen M, Song YQ, Lv LJ, Chen YX (2005) Analysis of Genetic Diversity and Relationship Among Some Chinese Domestic Ducks and Wild Ducks Using AFLP. J Xiamen Univ (Natural Science Edition) 5, 729-33

Received 7 April 2009, accepted 4 February 2010.

Corresponding author:

HUI-FANG LI

email: Ihfxf_002@yahoo.com.cn

Institute of Poultry Science, Chinese Academy of Agricultural Sciences, Yangzhou 225003, People's Republic of China 